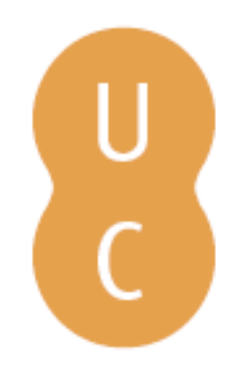

\title{
pompalina
}

\section{Historical fiction, brachylogy, and Plutarch's Banquet of th e Seven Sages}

Autor(es): Kim, Lawrence

Publicado por: Imprensa da Universidade de Coimbra; Centro de Estudos Clássicos e

URL

DOI: $\quad$ DOI:http://dx.doi.org/10.14195/978-989-8281-17-3_44

Accessed : $\quad$ 26-Apr-2023 12:50:01

A navegação consulta e descarregamento dos títulos inseridos nas Bibliotecas Digitais UC Digitalis, UC Pombalina e UC Impactum, pressupõem a aceitação plena e sem reservas dos Termos e Condições de Uso destas Bibliotecas Digitais, disponíveis em https://digitalis.uc.pt/pt-pt/termos.

Conforme exposto nos referidos Termos e Condições de Uso, o descarregamento de títulos de acesso restrito requer uma licença válida de autorização devendo o utilizador aceder ao(s) documento(s) a partir de um endereço de IP da instituição detentora da supramencionada licença.

Ao utilizador é apenas permitido o descarregamento para uso pessoal, pelo que o emprego do(s) título(s) descarregado(s) para outro fim, designadamente comercial, carece de autorização do respetivo autor ou editor da obra.

Na medida em que todas as obras da UC Digitalis se encontram protegidas pelo Código do Direito de Autor e Direitos Conexos e demais legislação aplicável, toda a cópia, parcial ou total, deste documento, nos casos em que é legalmente admitida, deverá conter ou fazer-se acompanhar por este aviso.

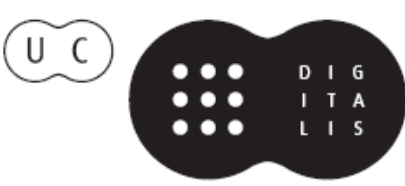




\section{Symposion and Philanthropia in Plutarch}

\section{José Ribeiro Ferreira, Delfim Leão Manuel Troster e Paula Barata Dias (eds.)}

IMPRENSA DA UNIVERSIDADE DE COIMBRA 


\title{
Historical fiction, Brachylogy, and Plutarch's BANQUET OF THE SEVEN SAGES
}

\author{
LAWRENCE Kim \\ University of Texas, Austin
}

\begin{abstract}
In this paper I examine the ways in which the weaknesses and strengths of Plutarch's Banquet of the Seven Sages are tied to Plutarch's attempt to recreate the world of the sixth century BCE in fictional form. The awkwardness of the first half of the dialogue stems from the incommensurability between the symposiastic genre of the Banquet and the Sages' role as 'performers of wisdom' and their noted brevity of speech, or brachulogia. It is only when Plutarch stops trying to historicize in the second half of the dialogue (and shifts his focus away from the Sages altogether) that it becomes more readable, literary, and Plutarchan. This disparity reflects a broader tension between archaic brachulogia, and the less definitive, ambivalent, and voluble style of discourse Plutarch favored, and I suggest that the Banquet stages its own internal dialogue between alternative modes of representing the past.
\end{abstract}

\section{Introduction}

The Banquet of the Seven Sages is something of an anomaly in Plutarch's works. As its title suggests, the work belongs to the genre of literary symposia, linked to the seminal texts of Plato and Xenophon as well as Plutarch's own Table Talk and other Imperial examples such as Lucian's parodic Symposium, or the Lapiths and Athenaeus' Deipnosophists. ${ }^{1}$. But the Banquet can also be classed more broadly as a dialogue, a form particularly favored by Plutarch, and within this category it stands out as one of only two "historical" dialogues in the Plutarchan corpus; the other is On Socrates' Daimonion'2. Both combine a narrative of a well-known event from the distant past-in one, the legendary dinner of the Sages at the home of Periander, tyrant of Corinth, and in the other, the liberation of Thebes in 379-with the sort of philosophical discussion familiar from Plutarch's other dialogues.

While several of Plutarch's biographies, most notably Solon and Pelopidas, cover analogous time periods, the composition of a fictional dialogue set at a particular place and moment in historical time presents somewhat different challenges relating to literary and dramatic composition. It seems that the early sixth-century BCE milieu of the Banquet, less well-documented and perhaps more alien in worldview to Plutarch than the Plato-inflected fourth-century setting of On Socrates' Daimonion, was the more difficult period to recreate

\footnotetext{
${ }^{1}$ On the symposiastic genre in Plutarch, see M. Vetta, 2000, and L. Romeri, 2002, for Imperial literary symposia in general.

${ }^{2}$ One could arguably include Gryllus, a dialogue between Odysseus and one of Circe's man-animals, but its heroic setting places it somewhat apart from the historical dialogues. On Plutarchan dialogue, see R. Hirzel, 1895, pp. 124-237, I. Gallo, 1998, L. van der Stockt, 2000, and R. Lamberton, 2001, pp. 146-87. Some of the dialogues of Heraclides Ponticus were similarly set in the distant past; cf. R. HirzeL, 1895, p. 138.
} 
successfully. Certainly On Socrates' Daimonion is widely considered to be one of Plutarch's best and most original literary works ${ }^{3}$, while the Banquet has not been judged as kindly by posterity ${ }^{4}$. My purpose here is to take a closer look at the Banquet as an experiment in writing historical fiction about the archaic period, focusing on the particular problems involved in incorporating the Seven Sages tradition and their celebrated brevity of discourse, or, brachulogia, into a symposiastic setting.

It might help to start with a brief sketch of the text. Like many of Plutarch's dialogues, the Banquet is framed as a retrospective narrative $(1 ; 146 \mathrm{~B}-\mathrm{C})$, here told by a certain Diocles, an expert in divination who was actually present at the dinner, to an equally unknown Nicarchus and a group of his friends. It opens with Diocles and one of the Sages, Thales of Miletus, making their way to Periander's home; they are joined by Niloxenus, a messenger conveying a letter from the Egyptian king Amasis to Bias of Priene (2;146D-148B). Upon their arrival, they meet Periander, their host, and the other six sages - Bias, Chilon, Cleobulus, Solon, Pittacus and Anacharsis (a fairly traditional list) but also several other guests - Cleobulus' daughter Cleobulina, known for her riddles, Aesop, Periander's wife Melissa, Solon's companion and disciple Mnesiphilus, the doctor Cleodorus, the poet Chersias and an otherwise unknown Ardalus (3-4; 146B-150D). Once the eating is done and the flutegirls have performed, the symposium proper begins. The first half features the Sages answering questions and offering advice, generally of a political nature, in a manner marked by brevity and rapidity $(5-12 ; 150 \mathrm{D}-155 \mathrm{D})$; the second half, signaled by the withdrawal of the women, Cleobulina and Melissa, features more extended speeches on loftier topics $(13-21 ; 155 \mathrm{E}-164 \mathrm{D})$. This part of the symposium is interrupted by the arrival of Periander's brother who tells the wondrous story of an event he has just witnessed: the arrival at Taenarum of Arion, conveyed by dolphins. After an ensuing discussion of dolphin-lore, the dinner comes to an abrupt conclusion, returning perfunctorily (the last sentence) to the framing narrative of Diocles 5 .

One of the most striking characteristics of the Banquet is the considerable disparity, in style and content, between the two halves of the text (1-12; 1321). The Sages dominate the first half of the dialogue; the conversation is rapid, consisting of short, sententious opinions, and the topics broached relate to human activity, such as politics and the household. In the second half, however, the non-Sages come to the fore, expounding long speeches on subjects of a more divine and cosmic significance familiar from Plutarch's other dialogues. ${ }^{6}$

${ }^{3}$ On this text, see, e.g., D. Babut, 1984, A. Barigazzi, 1988, and R. Lamberton, 2001, pp. $179-87$.

${ }^{4}$ U. von Wilamowitz-Moellendorff, 1890, p. 196 is the most incisive condemnation. For a long time many scholars were convinced that the Banquet was not by Plutarch at all, or, at least, could be dismissed as a youthful indiscretion. Few now doubt the work's authenticity-J. Defradas, 1954, conclusively demonstrated the unmistakably Plutarchan nature of the Platonically-influenced ideas expressed in the second part of the Banquet.

${ }^{5}$ D. E. Aune, 1978 , pp. 56-8 provides a convenient outline summary of the text.

${ }^{6}$ L. van der Stockt, 2000, p. 113. 
Each portion has occasioned negative appraisals: if the first half's sprinkling of the Sages' sayings has been criticized as "une sorte de recueil assez froid de maximes sur divers sujets" 7 , the second raises charges of gross anachronism - Solon and Cleobulus become virtually indistinguishable from Plutarch's relatives Lamprias or Soclaros in other dialogues ${ }^{8}$. Coming to grips with this stark split in subject matter and style is thus essential for fully evaluating and understanding the Banquet, ${ }^{9}$ and the failure to do so hampers recent attempts to recuperate the text by locating a unifying theme underlying the apparent convivial chaos - e.g., oikonomia, politics, love, a Platonic insistence on the power of the divine over the material. Even the best reading of the text, by Judith Mossman, who elegantly and persuasively argues that "the Dinner is a richly and allusively written piece whose dramatic context and narrative are inextricably entwined with its content...", ${ }^{10}$ concentrates on the introduction and the second half of the dialogue, which have been recognized as possessing considerable literary merit ${ }^{11}$, and elides the 'difficult' first half of the dinner.

In what follows, I examine the two halves of the dialogue as embodying different approaches on the part of Plutarch toward the problem of writing historical fiction set in a period embodying ideas and an aesthetic radically different from his own. In the first part of the Banquet, Plutarch's attempts to incorporate the traditional lore about the Sages into a symposiastic framework - that is, to be 'historically' faithful to the Sages' tradition - runs into serious difficulties; it is only when he abandons this historicizing goal in the second part, that the dialogue can take flight. But the two halves are also characterized by their contrasting discursive styles, and Plutarch, wittingly or no, reveals the tensions that exist between the brachulogia characteristic of the 'historical' Sages, and by extension the archaic period, and the less definitive, ambivalent, and voluble style of discourse he himself favored. In this sense, the Banquet stages its own internal dialogue between alternative modes of representing the past.

\section{Historicizing the Seven Sages}

Throughout the dialogue, but especially in its first half, Plutarch attempts to incorporate as much of the legendary tradition about the Sages as possible into his text in order to lend it the proper historicizing flavor and some semblance

${ }^{7}$ J. Defradas, 1954, p. 13, referring to chs. 5-12. Cf. R. Hirzel, 1895, pp. 139-40.

8 U. von Wilamowitz-Möllendorff, 1890, p. 196. Other anachronisms (Croesus, Periander, and Amasis as contemporaries; the presence of women (Eumetis and Melissa) at an archaic symposium (on this see J. M. Mossman, 1997, pp. 124-5; p. 137 n. 28)) were probably not of great concern to Plutarch, since the very idea of a dinner of the Seven Sages is difficult to square with chronology. J. Defradas, 1954, pp. 7-12 succinctly summarizes the debate; cf. 30 on questions of date.

9 Oikonomia: D. E. Aune, 1978, pp. 52-3; politics: G. J. D. Aalders, 1977; love: J. M. Mossman, 1997; Platonic: J. Defradas, 1954, p. 15.

${ }^{10}$ J. M. Mossman, 1997, p. 122.

${ }^{11}$ E.g., by J. Defradas, 1954, pp. 14-5. 
of authenticity ${ }^{12}$. The premise of the Banquet draws on a longstanding tradition that all of the Sages had gathered together at a symposium; the location varied, but Corinth is attested as one possibility ${ }^{13}$. Periander was often included in lists of the Seven Sages, but his credentials were also questioned, given his rather un-Sage-like portrayal in Herodotus. Plutarch's decision to have him host the banquet allows him to participate in the conversation without concerns about eligibility. The extensive guest list is an indication that Plutarch has tried to include as many familiar faces from the archaic period as possible; and in fact, reference is made during the conversation to many other well known figures of the time, such as Hesiod, Epimenides, Thrasybulus of Miletus, and Croesus. As the choice of characters suggests, the Banquet's evocation of the archaic world has, perhaps inevitably, a considerable Herodotean flavor. In fact, the text cannot help but exploit the temporal fixity of his symposium by activating readers' knowledge of the Histories; Mossman shows how the Banquet is suffused with "a good deal of underlying sadness and irony" when one considers the often tragic future in store for the guests: Periander's murder of Melissa, Solon's sad last days in Athens, Anacharsis'brutal death in Scythia, and Aesop's ignoble execution at Samos ${ }^{14}$.

The two pivotal episodes in each half of the dialogue-the reading and response of the letter from the Egyptian king Amasis, and the story of Arion and the dolphin - are inspired by Herodotus as well. The Arion tale is a marvelous rewriting of one of the most famous Herodotean narratives, which I discuss at the end of this article. The letter from Amasis to Bias is not from the Histories, but fits snugly into a Herodotean milieu. The use of letters by non-Greek monarchs is a well-known feature of Herodotus' world, and Amasis' epistolary correspondence with the tyrant Polycrates of Samos (3.40-43) would be familiar to any reader of the Histories. Moreover, Amasis' request to Bias for help is an example of another Herodotean topos, in which a monarch or tyrant receives advice from a 'wise man' or sage. Further thematic connections are brought out by a brief anecdote Thales tells Diocles en route to Periander's, about a previous 'epistolary' exchange between Bias and Amasis $(146 \mathrm{~F})$. Amasis had sent Bias an animal for sacrifice asking him to send back the best and worst portion of the meat. Bias responded to both requests by sending back only one body part - the tongue — an act of wisdom that gained him Amasis' respect and esteem ${ }^{15}$. The story is linked both to the Herodotean fondness for depicting symbolic, non-verbal communication (e.g., Thrasybulus

12 The specific sources are less important here than the fact that Plutarch makes a conscientious attempt to include sayings that were well-known in the Sages tradition.

${ }^{13}$ Plutarch refers to a banquet of the Sages at Periander's at Solon 4.1.D.L.I 40-44 mentions the Panionion, Corinth, and Delphi as attested locations, and remarks that Archetimus of Syracus also set it in Corinth, at the court of Cypselus (Periander's father) while Ephorus moved it to Croesus' court. For the tradition, see B. SNELL, 1954.

${ }^{14}$ J. M. Mossman, 1997, p. 126, and L. Inglese, 2002, pp. 66-7. Occasionally there is a pointed allusion: Thales' remark that Periander is making a good recovery from despotism $(147 \mathrm{C})$ concludes with an ominous "at least up till now", pointing to the disasters to come.

${ }^{15}$ On this story and its antecedents, see I. M. Konstantakos, 2004, pp. 97-119. 
and Periander: Hdt. 1.22) and the folktale motif, also found in his work, in which a ruler first tests an advisor before asking more important questions (Croesus' testing of the Greek oracles before selecting Delphi: Hdt. 1.46-48). In addition, Amasis' request falls into the category of the so-called 'riddle of the superlative', which consists of asking "what thing or person possesses a certain quality to the highest degree" and seems to have been a favorite device employed by monarchs in legend - the most famous example being Croesus' request to Solon to name the "most fortunate" man (Hdt. 1.29) ${ }^{16}$.

\section{Problems with Performance}

If the letter fits well with Plutarch's historicizing project by contributing to the archaic Herodotean atmosphere with which he imbues the Banquet, it comes across as somewhat unusual when considered against the symposiastic setting of the piece ${ }^{17}$. The symposium is traditionally a space for oral, improvisatory performance and public conversation, while a letter is written, planned, premeditated, and mute - a private communication between two individuals. Moreover, it would seem a priori difficult to incorporate a letter, which presupposes separation in time and space between writer and addressee, into the literary symposium's relatively restricted temporal and geographical frame ${ }^{18}$. This tension, however, is symptomatic of a wider problem that Plutarch had to grapple with when incorporating the historically attested stories about the Sages into a symposiastic milieu. On the face of it, the Sages would seem to fit extremely well into the spontaneous and face-to-face world of the symposium, especially since the well-known anecdotes and legends about the Sages depict them primarily as skilled performers of oral improvisatory wisdom. As Richard Martin has suggested, the Sages are often depicted as 'performing' wisdom, that is, giving advice or criticism, usually about political matters, in the form of 'public enactments' before an audience, generally a tyrant or other important $\operatorname{man}^{19}$. We can recall the well-known episodes involving the Sages in the first book of Herodotus: Solon's encounter with Croesus (1.29-33), Bias' quip to the same ruler about shipbuilding and horses (1.27), Chilon's advising Peisistratus' father not to have a son $(1.59)^{20}$. Such stories spotlight the Sages' fame for their ability to "shoot a brief, concise, and unforgettable remark, just like a skilled javelin thrower, that makes the person he's speaking

${ }^{16}$ On the 'riddles of the superlative', see I. M. Konstantakos, 2005, pp. 20-2 with extensive bibliography; quote from idem, 2004, p. 126.

${ }^{17}$ Cf. Lucian's Symposium 21-27, in which a letter from an absent angry philosopher disrupts the proceedings.

${ }^{18}$ L. Demarais, 2005, p. 90 comments on this aspect of the letter from Amasis, and her article compares the Banquet with the Letter of Aristaeus.

${ }^{19}$ R. Martin, 1993, pp. 115-16: “The sages are poets, they are politicians and they are performers...by perfomance, I mean a public enactment, about important matters, in word or gesture, employing conventions and open to scrutiny and criticism, especially criticism of style."

${ }^{20}$ On the individual Sages in Herodotus, see A. Busine, 2002, pp. 17-27. 
to seem no better than a child."21 The quotation is from Plato's Protagoras, in which Socrates claims more generally that the Sages' preference for terse, pithy opinions - their "laconic brevity" (brachulogia tis Lakônikê) — was "the characteristic style (tropos) of ancient philosophy (tôn palaiôn tês philosophias)" (343a-b). Plutarch knows this passage and the sentiment it expresses well and is committed to dramatizing this archaic brachulogia in his text.

But a closer consideration reveals some difficulties, and it is worth exploring them before turning to the letter itself. In Herodotus the effect of the Sages' bons mots arises from their appropriateness to a particular situation and addressee, and once the Sage utters his clever, incisive comment the anecdote abruptly comes to an end. In a biography, such as the Life of Solon, or those of individual Sages in Diogenes Laertius, these anecdotes can be linked as a series of encounters that occur at various points in a Sage's life, relatively unconnected in space and time. In a symposiastic dialogue, however, it is difficult to 'stage' these momentous scenes between Sage and ruler, not only because of the restrictions of the temporal and spatial setting, but also because the somewhat antagonistic nature of the anecdotes is not well-suited to the conviviality of a symposium.

The problem facing Plutarch then was how to include more than just a few of these 'performances', for which the Sages were famous, in a setting that was so unsuited to them. One solution is to insert famous quotes or anecdotes about a given Sage into the mouth of another character in the text: e.g., the story discussed above concerning Amasis, Bias, and the tongue is told by Thales. Another instance from the opening of the dialogue is when Niloxenus informs Diocles and Thales of Amasis' admiration for Thales' wisdom by relating two anecdotes illustrating this wisdom: Thales' method of measuring the pyramids and his quip that "a tyrant that lived to be old" was the most paradoxical thing he had ever seen ${ }^{22}$. So at the dinner proper, we find, to take only a few examples, Aesop quoting Solon and Eumetis (152D; 150E-F, 154B), Cleodorus quoting Pittacus (153E), and at one very odd moment Bias almost 'becomes' Thales, answering on his behalf with Thales' own sayings $(160 \mathrm{E})$. On one level, this is a tidy way out of the difficulty identified above; Plutarch can regale (or remind) his audience of the witty aphorisms of the Sages and include many more 'performance' stories than otherwise. One could also argue that the retrospective narration of the Sages' activities by their peers gives the impression both of the fame enjoyed by all of the Sages and their general familiarity with each other.

In a way though, this is also the problem. By having the Sages 'remind' the gathered company of their fellows' past activities, Plutarch characterizes these stories as already traditional at the time of the Banquet. The sense one gets within the narrative, however, is that they are not well-known at all, since

${ }^{21}$ P1. Protag. 342e; quoted by Plutarch at De garrul. 17; 510E.

22 147A-B. Cf. the slightly different versions of the pyramid-measuring story in D. L. 1.27 and Plin., Nat. 36.82. Plutarch himself attributes the tyrant remark to Bias at De adul. et am. 61c; cf. the much longer version at De gen. Socr. 578d. 
they are told in their entirety rather than just referred to in passing. Niloxenus, for example, insists on retelling the wisdom-stories about Thales in full, even though one of his addressees is the very person, Thales, that originally performed them ${ }^{23}$. Indeed, the presence of the Sages as audience to the telling of their own deeds and the quoting of their own words contributes considerably to the forced and artificial conversation that dominates the first half of the dialogue ${ }^{24}$. A more serious difficulty is that such a method fails to take advantage of the Banquet's setting and the presence of the Sages; we do not witness the Sages performing the improvised wisdom for which they are known, but only hear about things they have already done.

\section{The Letter of Amasis}

Plutarch's major task then is to engineer situations in which we can see the Sages in action, despite the incongruity of their performance style to the symposiastic milieu. One example occurs before the dinner begins: upon their arrival at Periander's Diocles and Thales are shown a baby centaur born in Periander's stables and after some speculation on the meaning of such a portent, Thales remarks to Periander that he should either avoid having young men take care of his horses, or else provide wives for them. Periander bursts out laughing, embraces Thales, and then the three enter the dining room; Thales' 'performance' concludes the episode. But during the dinner itself, once the guests have all settled in their places, such encounters become more difficult to choreograph. In what follows, I want to examine Plutarch's interesting, but ultimately fruitless, attempt to represent the oral improvisatory performance of the Sages by means of the introduction of a written letter into the symposium.

After the meal itself has been completed, the post-dinner discussion begins with Niloxenus' reading of Amasis' letter to Bias. In it, Amasis explains that the Ethiopian king and he are involved in a "contest of wisdom" (sophias hamilla) with each other, and that the Ethiopian has demanded that Amasis "drink the ocean" (ekpiein tên thalattan). If Amasis fails to solve this riddle, he will have to withdraw from the villages around Elephantine; if he solves it, he can lay claim to more Ethiopian territory. After a moment's thought, and some consultation with Cleobulus (who had a reputation as a riddle-master), Bias answers triumphantly: Amasis should offer to drink the ocean only after the Ethiopian king has stopped up the rivers flowing into it, since the agreement was to drink the ocean that exists now, and not in the future ${ }^{25}$. "As soon as Bias

${ }^{23}$ The effect is mitigated slightly by Thales' response, which is to correct Niloxenus' attribution to Thales — the tyrant quip was actually said by Pittacus of Mitylene — and add his own improvisatory variation.

${ }^{24}$ Compare the different effect in the second part of the dialogue when stories are told about famous figures who are not at the banquet, such as Epimenides or Hesiod.

${ }^{25} \mathrm{On}$ this category of riddle, known as the adynaton - an impossible situation or request that is often answered, as here, by proposing "an equally impossible counter-task...that logically precedes that of the propounder's adynaton", see I. M. Konstantakos, 2004, pp. 121-6 (quote 
had said these words, Niloxenus, hastened to embrace and kiss him out of joy and the rest of the company also commended the answer and expressed their satisfaction with it" (151D).

As we mentioned above, the monarchical letter to a wise advisor evokes Herodotus and the archaic period; the further epistolary relation referred to within the letter - the suggestion that in the old days Eastern monarchs conducted epistolary contests of wits with each other - was also ingrained in the popular tradition, and most likely derived from Egyptian and Near Eastern tales. The best example comes from the Aesop Romance, where Aesop becomes the special riddle advisor to the Babylonian king Lycurgus. The narrator explains: "In those days it was customary for kings to collect tribute from one another by means of contests in wit. They did not face one another in wars and battles, but sent philosophical conundrums by letter, and the one who couldn't find the answer paid tribute to the sender"(101). In the Banquet, however, Plutarch employs the letter to transform the standard face-to-face performance of advice between Sage and ruler into a display of wisdom before an audience of his peers. Unlike the above-mentioned references to past displays, Bias' performs his wisdom in the present, at the symposium itself; the reader too can witness the Sage in action. Normally in stories of this type, the sage's wisdom impresses either the king to whom he gives the advice, or the king whose riddle is defeated, but here neither Amasis nor the Ethiopian king is present. Rather it is Amasis' proxy Niloxenus and the dinner guests who provide the marveling response required by such stories. The letter has thus enabled an act of performative wisdom.

Once Bias has offered his successful riposte, however, another problem emerges. The conclusiveness of Bias' sententious solution to the Ethiopian king's riddle leaves the narrative at an impasse. In other depictions of Sages, such as in Herodotus, or the Life of Solon, the author can simply move on to another anecdote, another situation for the Sage to show off his aphoristic wisdom. In the Banquet, however, that is not possible; the cast of characters remain in place, and there is thus no natural way to continue the dinner conversation. The letter's strength, which was its ability to introduce by way of proxy a distant monarch into the symposium, is also its weakness - the absent Amasis cannot respond to the Sage's intervention.

Plutarch's solution to this dilemma is to have the Sages nevertheless act as if Amasis were present. The silence following Bias' answer is broken by Periander, who suggests that each Sage in turn advise Amasis as to "how he could render his kingship drinkable and sweet to his subjects." Starting with Solon, each sage offers a pithy response: e.g., "If only he is thoughtful" (Anacharsis); If he trust none of his associates"(Cleobulus); "If he should make his subjects fear, not him, but for him." (Pittacus). This 'rotation of wisdom' is repeated two more times during the first half of the dinner-regarding the best kind of democracy (154D) and the best managed household (154F-

from 123). Cf. D. E. Aune, 1978, p. 94. 
155D) - with equally banal results ${ }^{26}$. The practice, of course, has good sympotic precedent in both Plato and Xenophon ${ }^{27}$, and is a way to have every Sage, and not just Bias, contribute some wisdom, but the traditional brevity of the Sages' responses turns the exercise into a listing of platitudes addressed to a figure, Amasis, who is not even present at the dinner. Each aphorism thus loses the power that it might have possessed in a particular performative context. Furthermore, while juxtaposing the Sages' responses in this fashion allows greater participation, it also emphasizes their interchangeability ${ }^{28}$. No quote is particularly tailored to any one Sage; any quote could be re-attributed to another sage with little trouble, and in fact many of the Sages' maxims were interchangeable in the tradition ${ }^{29}$. Plutarch himself often ascribes them to different sages: the story about Bias and the tongue, for instance, is told of Pittacus in On Listening to Lectures (38C) and On Talkativeness (506C). This virtual identity of thought on the part of the Sages contrasts strongly with the diversity of opinions, philosophical allegiances, and professions that regularly feature at such gatherings, from Plato's Symposium to Plutarch's Table-Talk. In fact, the monotony of the Sages' responses can be contrasted with that of Periander, who, though not officially a Sage in this text, usually offers an eighth opinion in these roundabouts, reflective of his status as a tyrant, and hence individualized and somewhat opposed to those of the generally antityrannical Sages.

The "rotation of wisdom" has hardly succeeded as a means of giving life to Plutarch's fictional Sages, and in fact leaves matters right where it took them up: the brevity and conclusiveness of the Sages' aphorisms have ended rather than initiated further discussion. Plutarch falls back on his previous ploy; Niloxenus reveals that the letter from Amasis has a second part. In addition to the riddle posed to him by the Ethiopian king, Amasis had also received his opponent's replies to a set of questions that he had posed (What is the oldest thing? Time. The greatest? The kosmos. The wisest? Truth, etc.), and now was

${ }^{26}$ On Plutarch's use of these "tours de parole”, see L. Demarais, 2005, pp. 82-6, who views them in a more sympathetic light.

${ }^{27}$ P1. Smp.; Xen. Smp. 3-4.

${ }^{28}$ The lack of differentiation among the Sages is also suggested by Amasis' instructions to Niloxenus: "if Bias should give up trying to solve it, he should show the letter to the wisest men among the Greeks" (146E). The epithet "wisest of the Greeks" recalls the best-known story about the Sages, told in multiple versions, about the tripod or cup of Bathycles that is meant for 'the wisest' (Plutarch has Aesop jokingly allude to the legend in passing at $155 \mathrm{E}$ and tells his own version at Solon 4.2-7). The story goes that the object was sent first to one of the Sages, usually Thales or Bias, who then sent it to another, until the object had passed through the hands of all of them, and is either kept by Thales again, or dedicated to Delphi. The constant circulation of the tripod can be taken to highlight the humility of the sages and their respect for each other, but on another level it underlines their sameness and interchangeability. In this context the letter of Amasis is very much a stand-in for the tripod (which Plutarch almost ostentatiously fails to mention). For an overview of the entire tradition of the cup/tripod, see A. Busine, 2002, pp. 56-64.

${ }^{29}$ E.g., Thales' saying about animals, tyrants, and flatterers is attributed to Bias by Plutarch in Adul. et am. 61C; see above the other Thales and Bias stories told by Niloxenus. 
requesting an assessment of the responses ${ }^{30}$. This time the spokesman is Thales, who criticizes the Ethiopian's answers as incorrect and offers his own solutions instead: e.g., "God is oldest, for God is something that has no beginning." Thales' answers match ideas attributed to him by Diogenes Laertius (I 35), and a comparison with that text demonstrates how Plutarch has managed to take the bare skeleton of Thales' maxims and worked them into a context where he can be seen performing them. But the problem that arose with Bias' response is even more apparent here; Thales' Sage-like propensity for brevity results in a catalog of maxims or gnomai that brings an end to, rather than starts, discussion of the issue at hand. Even when the Sages do enact their wisdom onstage, as it were, their celebrated concision, or brachulogia, and the suddenness with which their responses get at the "truth", are ill suited to the extended conversation required by their presence together at a dinner. Plutarch tries to import some of the Sages' often antagonistic advice to rulers into the more harmonious rhythms of the symposium by directing Thales' criticisms to a king who is absent from the symposium. But the physical absence of that king significantly diminishes the effect of Thales' performance.

To conclude this section, it seems that the Sages, despite the fact that their associations with orality, performance, improvisation, and wisdom appear to qualify them as ideal candidates for depicting in a symposium, are actually quite unsuited to a symposiastic context; their tendency toward brevity, their status as contextualized performers, and their interchangeability all militate against the kind of dialogue that Plutarch was accustomed to writing.

\section{Arion, Anachronism, and Brachulogia}

The Banquet, however, changes dramatically in the second part of the dinner, beginning with the speech of Mnesiphilus, Solon's protégé, at 156B; from then on, not only does the conversation turn away from the political to matters of proper diet, the care of the body and finally religion, but the guests speak at length, represent a diversity of opinions, and espouse beliefs that are hard to imagine as conceivable in the sixth century BCE. We should note, however, that this criticism is valid only for this second half of the dinner; in fact, it is precisely when Plutarch stops trying to historicize, that is, when he stops trying to include the Sages' sayings and witticisms from the gnomological tradition, that the dialogue becomes more readable, more literary, more Plutarchan. Indeed he shifts his focus away from the Sages altogether; the non-Sages, who are individualized by their professions - the doctor Cleodorus, the diviner Diocles, and the poet Chersias - become more prominent as speakers, and when a famous contemporary figure is discussed, it tends to be one who is not present at the dinner, such as Epimenides, rather than one of the Sages themselves. And when a Sage does speak (e.g., Solon), he no longer does so in brief sound bites, but in the long elaborate speeches more characteristic of other Plutarchan dialogues.

\footnotetext{
${ }^{30}$ On the second part of the letter, see I. M. Konstantakos, 2005, pp. 36-44.
} 
It is instructive to compare the sections surrounding the letter from Amasis with the parallel 'Herodotean' episode in the second half of the dinner - the beautifully crafted retelling of the story of Arion and the dolphin ${ }^{31}$. The tale is told to the banqueters by Periander's brother Gorgus, who functions as the 'unexpected guest' familiar from other literary symposia and interrupts the banquet with news of the fabulous event he has just witnessed: a device that is also reminiscent of the way that exciting news arrives in the midst of Plutarch's 'dramatic dialogues' like Amatorius and On Socrates' Daimonion ${ }^{32}$. Technically, the story is another retrospective narrative, but the immediacy of the event, combined with its description by an eyewitness who has interrupted the dinner in order to bring the news, enables the fantasy of "being there" as "history" is made - much as the letter of Amasis allowed Plutarch, somewhat less successfully, to show the Sages in action.

In his presentation, Plutarch lays great emphasis on the wonder and religious mystery that the episode evokes. Arion's arrival is described from Gorgus' innocent perspective; during a moonlight sacrifice on the beach at Taenarum, a ripple is seen suddenly in the otherwise calm sea, surrounded by foam and noise, and begins moving rapidly toward the shore. All of those nearby raced down to the water, struck with wonder (thaumasantas); they saw a band of dolphins carrying a man's body, which, when deposited on the shore, was recognized as the citharode Arion. Arion himself tells Gorgus the familiar story of his near-death experience at the hands of pirates, but the whole episode, which Herodotus centers on the 'brave gesture' of Arion's leap and the punishment of his would-be murderers (the latter omitted by Plutarch), is reconceived as a religious epiphany:

Observing that the sky was dotted with stars, and that the moon was rising bright and clear, while the sea everywhere was without a wave as if a path were being opened for their course, [Arion] thought to himself that the eye of Justice is not a single eye only, but through all these eyes of hers God watches in every direction the deeds that are done on land and on the sea. (161E-F)

This elegant reworking of the marvelous as an instance of the divine revealing itself to the human world recalls the Delphic Dialogues, where similarly haunting tales, such as the Death of Pan, are told (De def. orac. 419A-E). And the speech Anacharsis gives in the Banquet to explain the behavior of the dolphins employs the same argument about the divine, the body, and the soul offered in On the Pythian Oracles (404B) ${ }^{33}$. Needless to say, the philosophical underpinning of Plutarch's recasting of the Arion story is completely alien to archaic thought, but it is at this moment, when he is the most unabashedly anachronistic, that he manages to best draw his audience

\footnotetext{
${ }^{31}$ On this episode, see J. M. Mossman, 1997, pp. 131-3; and the detailed comparison of L. INGLESE, 2002.

${ }^{32}$ On the 'dialogo drammatico', see A. Barigazzi, 1988.

${ }^{33}$ J. Defradas, 1954, p. 15; 111-2 n. 187 sees this idea as central to the Banquet.
} 
directly into the world of Archaic Greece and convey the sense of immediacy and wonder might have had for the people of that long ago time. Rather than stay faithful to his archaic 'sources', Plutarch chooses to portray the event from his own perspective and interests, and those of the members of his circle. The rewriting of the Arion episode is an excellent example of how Plutarch views an archaic narrative through his own Imperial and Platonizing lens, skillfully re-arranging its structure and re-focusing its thematic significance. Ironically in a work seemingly dedicated to bringing the world of the Sages to life, Plutarch has achieved his most vivid success with a story that has nothing to do with them-Arion's only connection to the guests is through Periander. The Sages, instead of serving as the main attraction, have become, along with the reader, the audience for a far more compelling narrative.

The length and leisurely pace of Gorgus' narrative, thick with description of the scene and Arion's thoughts, contrast strongly with the repartee and bons mots that make up the episode concerning the letter from Amasis. Moreover, whereas the Sages' pithy replies to the letter from Amasis ground the conversation to a halt, Gorgus' story of Arion engenders further discussionaside from Anacharsis' philosophical musings, the banqueters recall a series of dolphin stories that continue to dwell on the themes suggested by Gorgus' tale and carry the reader to the conclusion of the dialogue. The disparity is symptomatic of that between the two parts of the dialogue in general; the length and detail of the speeches in this last section are as characteristic of the second part of the dinner as the concise utterances are of the first. And as Laetitia Demarais has proposed, this inconsistency between the brachulogia of the opening of the symposium and the makrologia of its conclusion is so conspicuous that it must be the result of a deliberate move on Plutarch's part ${ }^{34}$. For Demarais, the difference is primarily due to content; while Plutarch's motive in the first part is to "show that brachylogy does not exclude profundity", he acknowledges in the second part that for certain, more metaphysical topics, "only macrology is relevant" 35 .

Although I think that some of the awkwardness in the first half of the Banquet is the unintentional result of Plutarch's failed struggle to smoothly incorporate traditional Sage-lore into a symposiastic context ${ }^{36}$, I agree that the shift between the first and the second half is so radical to suggest a more subtle design. But I see the juxtaposition of two halves, so different in form and content, as a sign of an underlying tension in Plutarch's thought between the kind of conversation, style, and philosophizing characteristic of the Sages (and by extension the Archaic period), and those on display in his other, contemporary, dialogues. After all, a certain ambivalence in Plutarch's view of the Sages can occasionally be glimpsed elsewhere in his corpus: the Sages' (predominantly democratic) political attitudes do not always accord well with

${ }^{34}$ L. Demarais, 2005, pp. 96-7.

${ }^{35}$ L. Demarais, 2005: quotes from p. 96.

${ }^{36}$ M. VETTA, 2000, p. 226 suggests that Plutarch might have intended to return to the text to revise and refine it. 
Plutarch's own, and in the Life of Solon, for example, he expresses some disdain for the Sages' primitive scientific knowledge (3.5) as well as moral disapproval of their opinions (7 on Thales' views on marriage and 20,23 on Solon's laws).

Most importantly perhaps, while Plutarch shows great respect for concision and brevity of speech in On Talkativeness (17.511A-B), Lycurgus (19-20), and specifically for the Sages' apophthegmata in On the Pythian Oracles $^{37}$, these qualities are entirely antithetical to Plutarch's own stylistic choices. The passage from On the Pythian Oracles, however, also testifies to Plutarch's vacillations on the relative virtues of brief and extended speech: the speaker, Theon, comparing the Delphic maxims attributed to the Sages to the straightforward prose of the present-day Pythia, points out that brevity can lead to obscurity rather than enlightenment. The Sages' maxims may be concise, but "if you were to examine what has been written and spoken about them by those wishing to learn what each one means, you would hardly find any discourses longer (logous makroterous) than these" (29.408E). And indeed while Theon praises concision and directness of speech, his own argument hardly displays these qualities, extending for pages and pages ${ }^{38}$. In the sort of ideal symposiastic or dialogic setting that Plutarch prefers to depict, concise sayings and maxims are meant to be unpacked and explored, their meanings and appropriateness discussed at length, and not simply stated and left alone.

The Banquet can be seen as a Plutarchan experiment in historical fiction, one that asks: is it better to historicize and portray the Sages as accurately as possible, to incorporate the evidence of the tradition into the dialogue, in an attempt to capture a sense of 'authenticity'? Or should one instead describe that past, the events and figures of that time, in a way more amenable to Plutarch and his Imperial audience, discussing ideas and topics of current interest in an anachronistic, but less alienating manner? It also poses the broader question of whether the style of discourse characteristic of the Sages and the archaic period is as appropriate for a properly philosophical and symposiastic conversation as the more expansive style adopted by Plutarch. By depicting each half of the Banquet in such discordant ways, Plutarch lets us make that choice for ourselves, but I suspect that many readers would agree that the aesthetic qualities and philosophical expressions of the dialogue's second half suggest that, to Plutarch at least, the archaic mode leaves something to be desired ${ }^{39}$.

${ }^{37}$ De Pyth. orac. 29.408 E-F. E.g. " “...he can accept and marvel at the maxims of the Sages..., because of their concision, as encompassing in a small size a compact and firmly-forged idea..."

38 The dialogue as a whole is structured as a debate on the clarity and ordinariness of simple unadorned prose and the elevated, yet obscurity and pretentiousness of poetic verse; the former is explicitly privileged, but one senses an uneasiness within the dialogue concerning that conclusion.

${ }^{39}$ As Mark Beck has pointed out to me, there surely must be a strong allusion to the discussion involving the Sages and brachylogy in Plato's Protagoras, as well as the more central debate in that dialogue between the relative efficacy of Protagoras' long speeches (makrologia) and Socrates' elenchus. 


\section{WORKS CITED}

Aalders, G. J. D., "Political Thought in Plutarch's Convivium Septum [sic] Sapientium", Mnemosyne, 30 (1977) 28-39.

Aune, D. E., "Septem Sapientium Convivium (Moralia 146B - 164D)", in H. D. Betz (ed.), Plutarch's Ethical Writings and Early Christian Literatures, Leiden, 1978, pp. 51-105.

Babut, D., "Le dialogue de Plutarque Sur le démon de Socrate. Essai d'interprétation", $B A G B, 1$ (1984) 51-76.

Barigazzi, A., "Plutarco e il dialogo 'drammatico", Prometheus, 14 (1988) 141-63.

Busine, A., Les sept sages de la Grèce antique. Transmission et utilisation d'un patrimoine légendaire d'Hérodote à Plutarque. Avec une postface de B. Decharneux, Paris, 2002.

Defradas, J., Plutarque: le Banquet des Sept Sages (ed., tr., comm.), Paris, 1954.

Demarais, L., "Sages et souverain à l'époque du banquet: le Banquet des Sept Sages et la Lettre d'Aristée à Philocrate”, in A. Casanova (ed.), Plutarco e l' età ellenistica. Atti del Convegno Internazionale di Studi (Firenze, 23 - 24 Settembre 2004), Firenze, 2005, pp. 79-103.

Gallo, I., "Forma letteraria nei 'Moralia' di Plutarco: Aspetti e problemi", ANRW, II.34.4 (1998) 3511-40.

Hirzel, R., Der Dialog. Zweiter Teil, Leipzig, 1895, pp. 132-48.

Inglese, L., "La leggenda di Arione tra Erodoto e Plutarco", Seminari Romani, 5 (2002) 55-82.

Konstantakos, I. M., "Trial by Riddle: The Testing of the Counsellor and the Contest of Kings in the Legend of Amasis and Bias", CEंM, 55 (2004) 85-138.

"Amasis, Bias and the Seven Sages as Riddlers", WJA, n. F. 29 (2005) 11-46.

Lamberton, R., Plutarch, New Haven, 2001.

Martin, R., “The Seven Sages as Performers of Wisdom”, in C. Dougherty \& L. Kurke (eds.), Cultural Poetics in Archaic Greece, Oxford, 1993, pp.108-28.

Mossman, J. M., "Plutarch's Dinner of the Seven Wise Men and Its Place in Symposion Literature", in J. M. Mossman (ed.) Plutarch and his Intellectual World, London, 1997, pp. 119-40. 
Romeri, L., Philosophes entre mots et mets. Plutarque, Lucien et Athénée autour de la table de Platon, Grenoble, 2002.

Snell, B., "Zur Geschichte vom Gastmahl der Sieben Weisen", in O. Hiltbrunner, H. Kornhardt \& F. Tietze (eds.) Thesaurismata. Festschrift für Ida Kapp zum 70. Geburtstag, München, 1954, pp. 10511.

van der Stockt, L., "Aspects of the Ethics and Poetics of the Dialogue in the Corpus Plutarcheum", in I. Gallo \& C. Moreschini (eds.) Plutarco e i generi letterari. Atti dell'VIII convegno plutarcheo (Pisa, 2-4 Giugno 1999), Naples, 2000, pp. 93-116.

Vetta, M., "Plutarco e il 'genere simposio", in I. Gallo \& C. Moreschini (eds.) Plutarco e i generi letterari. Atti dell'VIII convegno plutarcheo (Pisa, 2-4 Giugno 1999), Naples, 2000, pp. 217-29.

Wilamowitz-Möllendorff, U. von, "Zu Plutarchs Gastmahl der sieben Weisen”, Hermes, 25 (1890) 196-227. 